\title{
Autoimmune haemolytic anaemia in an asymptomatic carrier of hepatitis B virus
}

\author{
KAZUO YOSHIOKA AND HIROSHI MIYATA
}

Department of Paediatrics, Kinki University School of Medicine, Osaka, Japan

SUMMARY A patient with 'warm type' autoimmune haemolytic anaemia (AIHA) was also an asymptomatic carrier of hepatitis B virus (HBV). Although the direct antiglobulin test became negative after the anaemia had recovered spontaneously, antigenaemia of HBV persisted and the serum transaminase level remained normal or borderline. AIHA has not previously been described in association with the asymptomatic carrier state of HBV.

An association between infection and acute anaemia has long been noted. ${ }^{1}$ Zuelzer et al. ${ }^{2}$ suggested that occult viral infection (for instance, cytomegalovirus), might play a role in the development of autoimmune haemolytic anaemia (AIHA). We report a patient with AIHA who was an asymptomatic carrier of hepatitis B virus (HBV), and the relationship between AIHA, HBV infection, and a possible underlying immunological disturbance is discussed.

\section{Case report}

A 2-year-old Japanese boy was admitted on 11 July 1977 with a 2-week history of anaemia. He had previously been in good health and had no family history of anaemia or jaundice. Three weeks before admission he had an upper respiratory infection; 2 weeks later his mother noticed his pallor and jaundice. On admission, he was pale and had some enlarged neck glands on the left side, but no hepatosplenomegaly.

Hb $7.6 \mathrm{~g} / \mathrm{dl}$, RBC $2.49 \times 10^{12} / 1$, haematocrit $22.6 \%$, WBC $8.7 \times 10^{9} / 1$ (normal differential), platelets $410 \times 10^{9} / 1$, reticulocytes $5 \cdot 5 \%$, ESR $5 \mathrm{~mm}$ in the 1st hour; bone marrow, erythroid hyperplasia; serum bilirubin $0.3 \mathrm{mg} / 100 \mathrm{ml}(5 \cdot 1 \mu \mathrm{mol} / \mathrm{l})$, lactic dehydrogenase $360 \mathrm{U} / 1$ (100-225)*, AST $30 \mathrm{U} / 1$ $(7-40)^{*}$, ALT $43 \mathrm{U} / 1(<35)^{*}$, alkaline phosphatase $469 \mathrm{U} / 1(70-250)^{*}$, total protein $6.4 \mathrm{~g} / 100 \mathrm{ml}$ $(64 \mathrm{~g} / \mathrm{l})$, albumin $4 \cdot 4 \mathrm{~g} / 100 \mathrm{ml}(44 \mathrm{~g} / \mathrm{l})$, prothrombin time $100 \%$, and hepaplastin test $96 \%$. Direct antiglobulin test (DAGT) was positive; serum haptoglobin zero. The following tests gave negative results: osmotic fragility, Donath-Landsteiner, red *Normal values. cell fragility, serological test for syphilis, antinuclear antibodies, anti-DNA antibodies, and antithyroid antibodies. Cold agglutinin titre was normal. The RBC reacted with anti-IgG, anti-IgA, anti- $\kappa$ chain and anti- $\lambda$ chain serum, but not with anti-IgM or anti-C3 serum. The immunological findings were as follows; total number of lymphocytes $5 \cdot 829 \times 10^{9} / 1$, E-rosette forming cells $83 \%(70-85)^{*}$, Ig-bearing cells $16 \%(5-20)^{*}$, IgG-Fc receptor-positive T-cells $2 \%(2-8)^{*}$. Skin tests $(\mathrm{mm}) \dagger$; Candida sp. $12(<5)^{*}$, PPD 4.5, PHA $18(<5)^{*}$, serum immunoglobulin; IgG $1010 \mathrm{mg} / 100 \mathrm{ml}$ (209-633)*, IgA $85 \mathrm{mg} / 100 \mathrm{ml}$ (22-78)*, IgM $85 \mathrm{mg} / 100 \mathrm{ml}(97-155)^{*}$, IgD 5 $\mathrm{mg} / 100 \mathrm{ml}(0 \cdot 7-17)^{*}$, IgE $1651 \mathrm{IU} / \mathrm{ml}$ (21-1244)*, serum complement; C3 $68 \mathrm{mg} / 100 \mathrm{ml}(64-116)^{*}$ and C4 $24 \mathrm{mg} / 100 \mathrm{ml}$ (17-49)*. HBs-antigen (radioimmunoassay) was positive and anti-HBs antibody (passive haemagglutination) was negative in the serum. Liver biopsy was not performed. Serum titres to rubella, cytomegalovirus, adenovirus, Coxsackie A-9 virus, and mycoplasma were not raised.

The patient's mother had HBs- and HBe-antigen (micro Ouchterlony), and had normal liver function.

The haemolytic anaemia improved spontaneously; the patient was therefore discharged from the hospital 3 weeks after admission with $\mathrm{Hb} 11.5 \mathrm{~g} / \mathrm{dl}$, reticulocytes $0.4 \%$, positive DAGT, AST $18 \mathrm{U} / 1$, ALT $32 \mathrm{U} / \mathrm{l}$, and HBs-antigen positive. Three months later, the DAGT became negative. On 23 January 1979, investigations showed $\mathrm{Hb} 12.0 \mathrm{~g} / \mathrm{dl}$, AST $48 \mathrm{U} / 1$, ALT $53 \mathrm{U} / \mathrm{l}$, persistently positive HBs-antigen and negative anti-HBs antibody.

\section{Discussion}

AIHA is a rare complication of viral hepatitis. ${ }^{3}$ Habibi et al. ${ }^{4}$ stated that one of 80 children with AIHA was associated with hepatitis. There has been only a single case of latent hepatitis of type B accompanied by AIHA previously reported; $;$ the patient we report seems similar to that case. In the former case HB-antigen disappeared from the serum soon after the cure of anaemia, but this did not occur in our patient. It is difficult to attribute immunological haemolysis to HBV infection or liver †Diameter of erythema at $\mathbf{4 8}$ hours. 
damage in our patient, as speculated by Vachon et al., ${ }^{5}$ because liver function was normal or borderline, and HBV antigenaemia persisted even after the anaemia improved and the DAGT had become negative. The role of $\mathrm{HBV}$ in the pathogenesis of AIHA has thus been unclear.

From many recent studies of type $B$ hepatitis ${ }^{6}$ it is suggested that a defect of cell-mediated immunity may yield the carrier state of HBV. This hypothesis is consistent with the fact that newborn babies may be infected from their HBV-carrier mother, resulting in the persistent carrier state. ${ }^{7}$ Likewise, the role of cellular immunity in the pathogenesis of AIHA has become clearer. Krüger et al. ${ }^{8}$ suggested that an imbalance between reduced T-cells and increased but uncontrolled humoral immune response towards red cell antigens may lead to immunological haemolysis.

Taking these suggestions into consideration, it is possible that in our patient AIHA was induced by an upper respiratory infection or some other agent, in the presence of an immunological defect which permitted the HBV carrier state. Further study will be necessary to confirm the relationship between persistent HBV antigenaemia and AIHA. Zuelzer et $a .^{2}$ have attached importance to cytomegalovirus as a virus with which occult infection was observed in children with AIHA. It appears that attention should also be paid to HBV. None of the immuno- logical tests in our patient showed any abnormality, nor was there any evidence of other autoimmune disease.

\section{References}

1 Dacie J V. The autoimmune haemolytic anaemia. In: The haemolytic anaemias; congenital and acquired. Part 2. London: Churchill, 1962: 539.

2 Zuelzer W W, Mastrangelo R, Stulberg C S, Poulik M D, Page R H, Thompson R I. Autoimmune hemolytic anemia. Natural history and viral-immunologic interactions in childhood. Am J Med 1970; 49: 80-93.

3 Barrett-Connor E. Anemia and infection. Am J Med 1972; 52: 242-53.

4 Habibi B, Homberg J-C, Schaison G, Salmon C. Autoimmune hemolytic anemia in children. A review of 80 cases. Am J Med 1974; 56: 61-9.

5 Vachon A, Tuaillon J, Jean-Louis Ph, Evreux M. Acute haemolytic anaemia due to autoantibody associated with Hb antigen. $J$ Med Lyon 1975 ; 56 : 1123-5.

${ }^{6}$ Eddleston A L W F, Williams R. Inadequate antibody response to HBAg or suppressor T-cell defect in development of active chronic hepatitis. Lancet 1974 ; 2 : 1543-5.

7 Okada K. Maternal transmission of hepatitis B virus. In: Japan Medical Research Foundation, ed. Hepatitis viruses. Tokyo: University of Tokyo Press, 1978: 145.

8 Krüger J, Rahman A, Mogk K-U, Mueller-Eckhardt C. $T$ cell deficiency in patients with autoimmune haemolytic anaemia (warm type). Vox Sang 1976; 31: 1-12.

Correspondence to Dr Kazuo Yoshioka, Department of Paediatrics, Kinki University School of Medicine, 380 Nishiyama, Sayama-cho, Minami Kawachi-gun, Osaka, Japan 589.

\title{
Perineal amoebiasis
}

\author{
J M WYNNE \\ Department of Paediatric Surgery, Livingstone Hospital, Port Elizabeth, South Africa
}

SUMMARY A 14-month-old girl with invasive perineal amoebiasis is reported. There was destruction of the anus, the rectovaginal septum, the pelvic floor, and the perineum. The rapid progress and destructive potential of perineal amoebiasis is noted and the benefits of diagnostic awareness emphasised. Treatment with metronidazole will prevent further damage.

Amoebiasis may spread to affect the perineum or the female genitalia. ${ }^{1-6}$ The lesions are often superficial and of long duration ${ }^{4}$ but in children may be rapidly invasive $^{35}$ The infection can produce extensive ulceration around a colostomy or ileostomy. ${ }^{7}$ An undermined, spreading ulcer may start in drainage sites or surgical wounds after surgery to a patient suffering from amoebiasis. ${ }^{25}$

The following case is reported to illustrate the destructive potential of the parasite in the perineum of a child.

\section{Case report}

The patient, a 14-month-old girl of mixed descent, was referred from a country hospital where she had been admitted with a 2-week history of diarrhoea. While in hospital she had developed a perianal abscess which had burst.

Examination showed a seriously ill, toxic, pyrexial, anaemic child. Further abnormal findings were confined to the perineum where there was extensive 